\title{
УДК: 635.925(477.44)
}

DOI: 10.37128/2707-5826-2019-3-16

\section{СУЧАСНИЙ СТАН ТА ПЕРСПЕКТИВИ ВИКОРИСТАННЯ ОДНОРІЧНИХ КВІТНИКОВО-ДЕКОРАТИВНИХ РОСЛИН В ОЗЕЛЕНЕННІ ПАРКОВОЇ ЗОНИ ВІННИЦЬКОГО НАЦІОНАЛЬНОГО АГРАРНОГО УНIВЕРСИТЕТУ \\ Г.В. ПАНЦИРЕВА, канд. с.-г. наук, старший викладач, Вінницький національний аграрний університет}

Проаналізовано сучасний стан напрямків використання однорічних квітниково-декоративних культур в зоні Поділля та визначено їх перспективність для озеленення паркової зони ВНАУ. Вивчено та досліджено найбільи перспективні види та сорти культур родини Айстрові (Acteraceа L.): нагідки лікарські (Calendula officinalis L.), циинія вузьколиста (Zinnia aqnustifolla H.), чорнобривці прямостоячі (Tagetes erecta L.) ma айстра однорічна (Callistephus chinensis L.), - екологічно пластичних рослин, стійких до лімітуючих факторів довкілля та з тривалими декоративними властивостями протягом вегетаційного періоду. Виявлено найбільи перспективні сорти вітчизняної селекції для створення колекції однорічних культур на базі експозиційної ділянки Вінницького національного аграрного університету: нагідки лікарські (Сониее Єгипту, Каблуна, Гейша), цчинія вузьколиста (Глоріениа, Сомбреро, Класік), чорнобривцуі прямостоячі (Тітан, Вавіла, Робін Гуд), айстра однорічна (Художня, Яблунева, Аметист). Вивчаючи динаміку тривалості цзвітіння досліджуваних сортів, встановлено, щуо найвищі показники тривалості извітіння (до 60 днів) були встановлені y Tagetes erecta L. (сорт Тітан - 52 дні, сорт Ваніла - 60 днів, сорт Робін Гуд - 55 днів). Також нами узагальнені рекомендації щзодо використання різних культиварів досліджуваних однорічників закордонної селекції в озелененні з урахуванням їх біоморфологічних особливостей. Встановлено, щзо з практичної точки зору вони $\epsilon$ перспективними для створення груп на фоні газону, міксбортерів, рабаток, клумб та є чудовим матеріалом для створення моносадів. Саме розширення варіантів простих $і$ комплексних садових композицій з їх участю надасть парковій зоні ВНАУ більш декоративного вигляду, результати досліджень будуть використані для курсу лекиій та практичних занять за програмою спечіальності 206 «Садово-паркове господарство» для студентів факультету агрономї та лісівництвва Вінницького національного аграрного університету.

Ключові слова: Acteracea L., культивар, природний ареал, період иявітіння, варіанти використання, озеленення, ландшафтний дизайн.

Табл. 3. Рис. 1. Літ.15. 
Постановка проблеми. Збагачення та оновлення асортименту декоративних рослин $є$ одним 3 визначальних шляхів поліпшення стану озеленення та збільшення біорізноманіття для будь якої країни світу, у тому числі і України. Введення у широку виробничу практику нових перспективних видів та сортів, відібраних у результаті багаторічних досліджень, залишається одним з основних завдань декоративного садівництва [1].

Серед великої кількості квітниково-декоративних рослин найпитомішими $\epsilon$ непримхливі та екологічно пластичні рослини, стійкі до лімітуючих факторів довкілля, з тривалим декоративним виглядом протягом вегетаційного періоду. Саме дані характеристики притаманні провідним квітниково-декоративним видам як нагідки лікарські (Calendula officinalis L.), цинія вузьколиста (Zinnia aqnustifolla H.), чорнобривці прямостоячі (Tagetes erecta L.) та айстра однорічна (Callistephus chinensis L.) [2].

На сьогодні особливо актуальними є дослідження тривалості цвітіння однорічних квітниково-декоративних рослин в умовах урбанізованого середовища, комплексне оцінювання успішності інтродукції, декоративних якостей і господарсько-біологічних ознак, а також відбір перспективних видів і сортів для використання в умовах паркової зони Вінницького національного аграрного університету. Отже, опрацювання даних питань становитиме вагомий внесок для декоративного садівництва в цілому, у першу чергу такого iï підрозділу як інтродукція рослин, а також для практичного квітникарства й ландшафтного дизайну [3].

Аналіз останніх досліджень і публікацій. За сучасних умов бурхливого розвитку житлового i промислового будівництва актуальності набуває проблема озеленення населених місць, складовою частиною якого $є$ квітниководекоративні рослини, в тому числі і однорічні. На сьогодні існує широкий спектор квітниково-декоративних рослин. Серед них до числа найбільш перспективних для озеленення територій, оформлення квітників, парків i лісопарків належать рослини родини Acteraceae: культивари нагідків лікарських (Сонце Єгипту, Каблуна, Гейша), цинії вузьколистої (Глоріенша, Сомбреро, Класік), чорнобривців прямостоячих (Тітан, Вавіла, Робін Гуд), айстри однорічної (Художня, Яблунева, Аметист) [4].

Вони займають одне 3 провідних місць у світовому асортименті декоративних культур світової флори. Питання випробування даних видів і їх впровадження $\epsilon$ досить актуальними, а отримані результати досліджень здійснюють вагомий внесок для галузі квітникарства і ландшафтного дизайну. Маючи високі декоративні якості і широкі можливості їх застосування, дані види рослин становлять великий інтерес для квітникарства як цінне джерело для поповнення асортименту однорічних квітниково-декоративних культур [5].

Однорічні рослини за своїми біологічними властивостями $\epsilon$, зазвичай, більш атрактивними об'єктами, що мають більш рясне цвітіння, певні декоративні або інші властивості, що здебільшого перевершують значущість 
нескладних у догляді багаторічних рослин. Так, однією із найбільших переваг однорічників є виключна стійкість окремих видів до посухи та приморозків [9].

Селекційна робота із створення нових високопродуктивних, пристосованих до місцевих умов досліджуваних перспективних квітниководекоративних однорічних рослин у нашій країні практично відсутня. Проаналізувавши дані Державного реєстру сортів України встановлено, що із досліджуваних видів наявні лише 40 культиварів айстри однорічної 3 останньою реєстрацією у 2006 році. Тому виникає гостра потреба для більш детального вивчення морфо-біологічних особливостей досліджуваних декоративних видів $[6,10]$.

Мета та об'єкт досліджень. Проаналізувати декоративні характеристики однорічних квіткових рослин з метою озеленення паркової зони Вінницького національного аграрного університету. Відповідно до мети основним завданням було виявлення найбільш перспективних сортів вітчизняної селекції для створення колекції однорічних культур. Результати досліджень будуть використані для курсу лекцій та практичних занять за програмою спеціальності 206 «Садово-паркове господарство» для студентів агрономічного факультету Вінницького національного аграрного університету.

Методика та умови досліджень. Об'єктом для досліджень були представники родини Айстрові (Asteraceae), а саме сорти та гібриди нагідків лікарських (Calendula officinalis L.), цинії вузьколистої (Zinnia aqnustifolla H.), чорнобривців прямостоячих (Tagetes erecta L.) та айстри однорічної (Callistephus chinensis L.).

Дослідження проводили протягом 2016-2018 рр. на базі паркової зони Вінницького національного аграрного університету. Грунтово-кліматичні умови зони дослідження сприятливі для вирощування досліджуваних видів [7].

Результати досліджень. Впровадження у широку виробничу практику нових перспективних видів і форм рослин, відібраних в результаті багаторічних досліджень, залишається одним з основних завдань інтродукції.

У сучасних умовах для України актуальність цих питань підсилюється ще й тим, що асортимент декоративних культур, які використовуються в нашій країні поки недостатній. Інтродукція досліджуваних представників для озеленення дозволить значно розширити асортимент декоративно цінних рослин та збагатити культивовану флору України.

Враховуючи різноманіття квітниково-декоративних видів представників родини Айстрові (Asteraceae) за призначенням, кольоровою гамою, габітусом, формою декоративних елементів, а також ї значна кількість у культурі розвинених країн світу. Беручи до уваги факт їх незначної кількості в цій галузі нашої держави питання визначення можливостей та шляхів використання потенціалу цих рослин для збагачення культигенної фракції флори $є$ важливим як 3 наукової, так і практичної точок зору. Його вирішення стане суттєвим 
кроком на шляху підвищення якості вітчизняного асортименту квітниководекоративних рослин $[2,11]$.

Айстрові (Asteraceae L.) - родина рослин, найбагатша за кількістю видів серед е удікотів: включає понад 30000 видів, які входять у майже 2000 родів. Її представники поширені на всіх континентах (крім Антарктиди) і зустрічаються у різних рослинних угрупуваннях. У флорі України зустрічається 695 видів, що належать до 121 роду [1, 8, 12].

Проаналізувавши праці вітчизняних та світових науковців, таких як Іщук Л.П., Олешко О.Г., Черняк В.М, Алєксеєва Н.М., Харіс М. та ін. нами описано природні ареали досліджуваних представників родини Asteraceae L. (табл. 1) [1-8, 14].

Таблиия 1

Природні ареали представників родини Asteraceae L. та показники мінімальних температур їх природних місцезростань

\begin{tabular}{|c|c|c|c|}
\hline № & Назва виду & Природний ареал виду & $\begin{array}{c}\text { Мінімальні } \\
\text { температури, }\end{array}{ }^{\circ} \mathrm{C}$ \\
\hline 1 & $\begin{array}{c}\text { Айстра однорічна } \\
\text { (Callistephus chinensis } \\
\text { (L.) Nees) }\end{array}$ & $\begin{array}{c}\text { Свропа, Азія, Північна Африка, } \\
\text { Центральна і Північна Америка }\end{array}$ & $-3,9-12,3$ \\
\hline 2 & $\begin{array}{c}\text { Нагідки лікарські } \\
\text { (Calendula officinalisL.) }\end{array}$ & $\begin{array}{c}\text { Греція, Туреччина, Ліван, Сирія, } \\
\text { Ізраїль, Західна Іорданія }\end{array}$ & $-7,8-12,5$ \\
\hline 3 & $\begin{array}{c}\text { Цинія вузьколиста } \\
\text { (Zinnia aqnustifolla H.) }\end{array}$ & США, Канада & $-5,7-12,3$ \\
\hline 4 & $\begin{array}{c}\text { Чорнобривці } \\
\text { прямостоячі } \\
\text { (Tagetes erecta L.) }\end{array}$ & Центральна і Північна Америка & $-4,4-12,0$ \\
\hline
\end{tabular}

Примітка: Інформація наведена для роду, види якого використовуються в декоративному садівництві

Джерело сформовано на основі результатів досліджень

За даними літературних джерел усі представники родини Айстрові розповсюджені в Європі, Азії, Північній Африці, Центральній і Північній Америці, Україні, Росії; ростуть на луках, у світлих лісах, на узліссях, вапнякових схилах, в ярах і річкових долинах $[2,3,15]$.

Проаналізувавши Державний реєстр сортів України встановлено, що селекційна робота зі створення досліджуваних квітниково-декоративних рослин в Україні не ведеться, окрім айстри однорічної (40 сортів). На сьогодні світовий асортимент календули лікарської (Calendula officinalis L.), цинії вузьколистої (Zinnia aqnustifolla H.), чорнобривців прямостоячих (Tagetes erecta L.) та айстри однорічної (Callistephus chinensis (L.) Nees) досить широкий. Основними напрямками використання сортів та гібридів досліджуваних рослин $\epsilon$ декоративний (озеленення, зріз) та лікарський $[8,14]$. 
За результатами досліджень наведені основні морфометричні показники (висота рослин, діаметр та забарвлення квітки, строки цвітіння) декоративноцінних сортів однорічних квітниково-декоративних рослин (табл. 2).

Таблиця 2

Морфометричні показники досліджуваних сортів (гібридів) однорічних квітниково-декоративних рослин в умовах паркової зони ВНАУ

\begin{tabular}{|c|c|c|c|c|c|c|c|}
\hline № & $\begin{array}{l}\text { Вид / сорт } \\
\text { (гібрид) }\end{array}$ & $\begin{array}{c}\text { Висота } \\
\text { рослин, } \\
\text { см }\end{array}$ & $\begin{array}{c}\text { Діаметр } \\
\text { квітки, } \\
\text { см }\end{array}$ & $\begin{array}{l}\text { Строки } \\
\text { цвітіння }\end{array}$ & $\begin{array}{c}\text { Забарвлення } \\
\text { квітки }\end{array}$ & Аромат & $\begin{array}{l}\text { Форма } \\
\text { квітки }\end{array}$ \\
\hline $\mathrm{I}$ & \multicolumn{7}{|c|}{ Нагідки лікарські (Calendula officinalis L.) } \\
\hline 1 & $\begin{array}{l}\text { Сонце } \\
\text { Сгипту }\end{array}$ & до 18 & до 5 & $\begin{array}{l}\text { середньо- } \\
\text { пізній }\end{array}$ & $\begin{array}{c}\text { червоні } 3 \\
\text { темною } \\
\text { серединою } \\
\end{array}$ & ароматна & махрові \\
\hline 2 & Каблуна & до 25 & до 10 & пізній & $\begin{array}{c}\text { яскраво- } \\
\text { помаранчеві }\end{array}$ & ароматна & напівмахрова \\
\hline 3 & Гейша & до 30 & до 15 & середній & $\begin{array}{c}\text { помаранчевий } \\
\text { з червоними } \\
\text { кінчиками }\end{array}$ & ароматна & густомахрова \\
\hline II & \multicolumn{7}{|c|}{ Цинія вузьколиста (Zinnia aqnustifolla H.) } \\
\hline 1 & Глоріенша & до 25 & до 10 & середній & $\begin{array}{c}\text { темно- } \\
\text { помаранчеві }\end{array}$ & слабкий & махрова \\
\hline 2 & Сомбреро & до 30 & до 12 & пізній & $\begin{array}{c}\text { червоно- } \\
\text { коричневого } \\
\text { відтінку } 3 \\
\text { помаранчевою } \\
\text { облямівкою } \\
\end{array}$ & ароматна & напівмахрова \\
\hline 3 & Класік & до 30 & до 15 & ранній & біле & слабкий & проста \\
\hline III & \multicolumn{7}{|c|}{ Чорнобривці прямостоячі (Tagetes erecta L.) } \\
\hline 1 & Тітан & до 20 & до 8 & пізній & помаранчеве & ароматна & $\begin{array}{c}\text { напівмахров } \\
\text { а,хризантем } \\
\text { о-подібна }\end{array}$ \\
\hline 2 & Ваніла & до 15 & до 5 & $\begin{array}{l}\text { середньо- } \\
\text { пізній }\end{array}$ & $\begin{array}{c}\text { жовтувато- } \\
\text { біле }\end{array}$ & ароматна & \begin{tabular}{|c|} 
махрова, \\
гвоздикоподібн \\
$\mathrm{a}$ \\
\end{tabular} \\
\hline 3 & Робін Гуд & до 18 & до 8 & пізній & $\begin{array}{l}\text { яскраво } \\
\text { червоне }\end{array}$ & ароматна & проста \\
\hline IV & \multicolumn{7}{|c|}{ Айстра однорічна (Callistephus chinensis (L.) Nees) *** } \\
\hline 1 & Художня & до 60 & до 14 & середній & біле & слабкий & густомахрова \\
\hline 2 & Яблунева & до 70 & до 16 & $\begin{array}{l}\text { середньо- } \\
\text { пізній }\end{array}$ & рожеве & слабкий & махрова \\
\hline 3 & Аметист & до 40 & до 10 & пізній & $\begin{array}{c}\text { темно- } \\
\text { фіолетове }\end{array}$ & слабкий & проста \\
\hline
\end{tabular}

** Інформація наведена для виду, сорти якого використовуються в декоративному садівництві

*** Сорти занесені до Державного Реєстру сортів України

Джерело сформовано на основі результатів досліджень 
Таким чином, природні можливості досліджуваних однорічних квітниководекоративних рослин, пластичність до зміни їх життєвої форми, висока якість за сукупністю ознак, що визначають їх надзвичайну декоративність характеризує дані сорти, як джерело для збагачення асортименту декоративних культур в Україні.

Вивчаючи фазу цвітіння, детально досліджували його динаміку. Дані щодо тривалості цвітіння подано у зведеній діаграмі (рис.1).

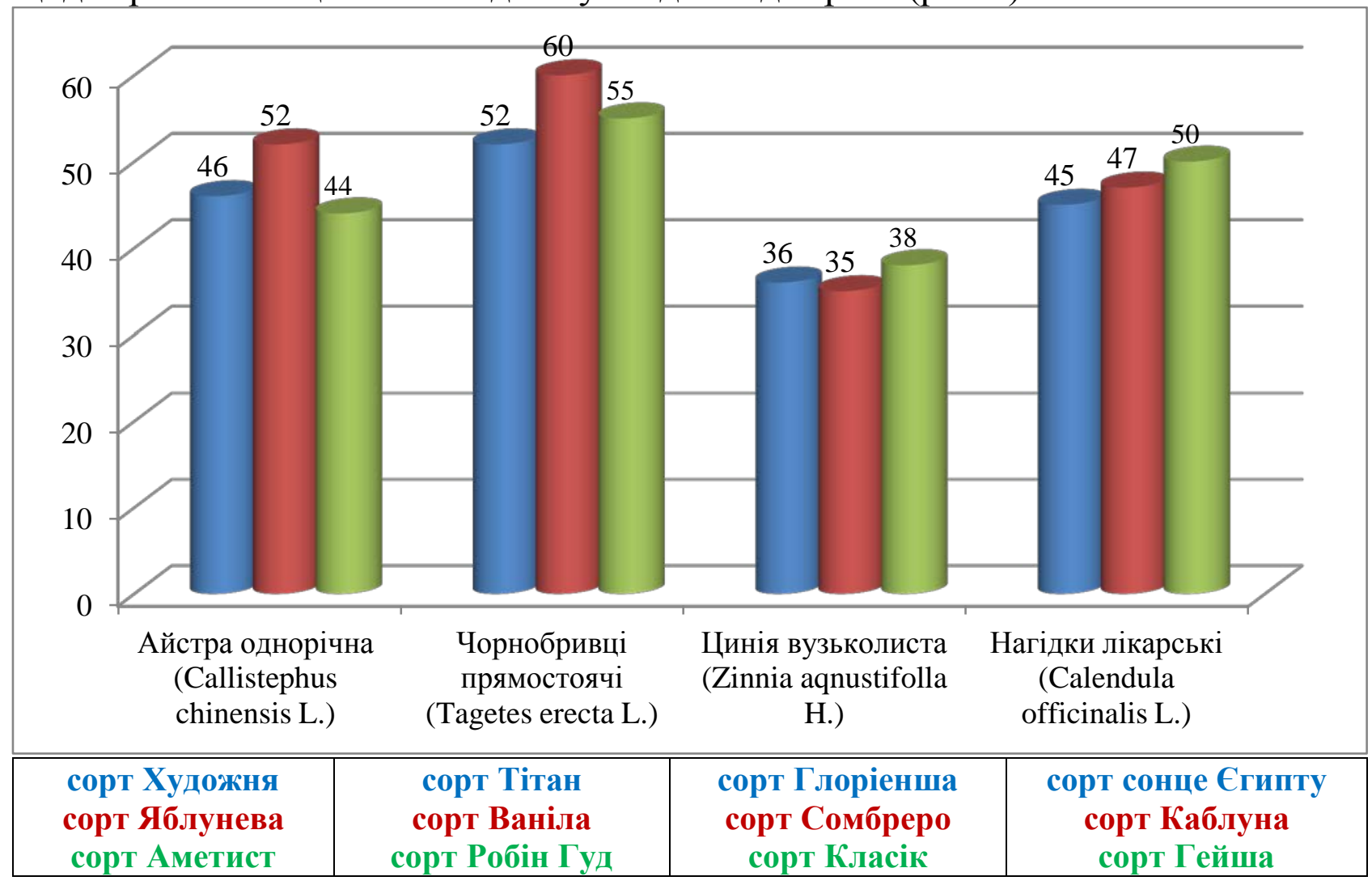

Рис. 1. Динаміка тривалості цвітіння основних квітниководекоративних однорічних рослин, днів.

Джерело сформовано на основі результатів досліджень

Найвищі показники тривалості цвітіння (до 60 днів) були встановлені у Tagetes erecta L. (сорт Тітан - 52 дні, сорт Ваніла - 60 днів, сорт Робін Гуд - 55 днів). Дещо нижчі показники були зафіксовані у Callistephus chinensis (L.) Nees (сорт Художня - 46 днів, сорт Яблунева - 52 дні, сорт Аметист - 44 дні) [8, 15].

Узагальнені рекомендації щодо використання різних сортів досліджуваних однорічних квітниково-декоративних рослин закордонної селекції в озелененні 3 урахуванням їх біоморфологічних особливостей наведені в табл. 3.

Дослідженнями встановлено, що 3 практичної точки зору вони $\epsilon$ перспективними для створення груп на фоні газону, міксбортерів, рабаток, клумб та є чудовим матеріалом для створення моносадів. Усі досліджувані види закордонної селекції, проте вони різняться за розмірами i формами, 
Таблиия 3

Рекомендації з використання основних квітниково-декоративних однорічних рослин

\begin{tabular}{|c|c|c|c|}
\hline Назва виду & $\begin{array}{l}\text { Життєва } \\
\text { форма }\end{array}$ & $\begin{array}{c}\text { Період } \\
\text { збереження } \\
\text { декоративності } \\
\text { зрізаних квітів у } \\
\text { воді, днів }\end{array}$ & $\begin{array}{c}\text { Рекомендації } 3 \\
\text { використання }\end{array}$ \\
\hline $\begin{array}{c}\text { Нагідки лікарські } \\
\text { (Calendula officinalis L.) }\end{array}$ & однорічник & до 8-12 & $\begin{array}{c}\text { групові та поодиночні } \\
\text { посадки, міксбордер, } \\
\text { рабатки, клумби, } \\
\text { бордюр, } \\
\text { монокультурні сади } \\
\end{array}$ \\
\hline $\begin{array}{c}\text { Цинія вузьколиста (Zinnia } \\
\text { aqnustifolla H.) }\end{array}$ & однорічник & до 6-8 & $\begin{array}{c}\text { альпінарії } \\
\text { групові міксбордер, } \\
\text { рабатки, клумби, } \\
\text { бордюр, монокультурні } \\
\text { сади }\end{array}$ \\
\hline $\begin{array}{l}\text { Чорнобривці прямостоячі } \\
\text { (Tagetes erecta L.) }\end{array}$ & однорічник & до 13-15 & $\begin{array}{c}\text { на зріз, групові та } \\
\text { поодиночні посадки, } \\
\text { міксбордер, } \\
\text { букети, рабатки, } \\
\text { клумби, бордюр, } \\
\text { підпірні стінки, } \\
\text { солітери на фоні газону, } \\
\text { монокультурні сади } \\
\end{array}$ \\
\hline $\begin{array}{c}\text { Айстра однорічна } \\
\text { (Callistephus chinensis (L.) } \\
\text { Nees) }\end{array}$ & однорічник & до 10-14 & $\begin{array}{c}\text { на зріз, групові та } \\
\text { поодиночні посадки, } \\
\text { міксбордер, } \\
\text { букети, рабатки, } \\
\text { клумби, бордюр, } \\
\text { підпірні стінки, } \\
\text { солітери на фоні газону, } \\
\text { монокультурні сади }\end{array}$ \\
\hline
\end{tabular}

** Інформачія наведена для виду, сорти якого використовуються в декоративному садівниитві

Джерело сформовано на основі результатів досліджень

забарвленням, будовою квітів, тривалістю цвітіння тощо. Саме збагачення сортової різноманітності квітниково-декоративних видів однорічників, розширення варіантів простих і комплексних садових композицій з їх участю, більш рівномірне їх розміщення в парковій зоні Вінницького національного 
аграрного університету, значно наблизить оформлення міста Вінниця та населених міст України до рівня кращих світових зразків.

Висновки і перспективи подальших досліджень. Встановлено, у галузі садівництва однорічні види квітниково-декоративних рослин представлені як значною кількістю видів, так і багатим сортовим асортиментом, лише закордонної селекції.

3 практичної точки зору усі досліджувані сорти та гідриди закордонної селекції викликають інтерес як потенційно цінні об'єкти для збагачення асортименту квітниково-декоративних рослин України та $є$ перспективними для оновлення асортименту паркової зони на базі Вінницького національного аграрного університету.

\section{Список використаної літератури}

1. Pantsyreva H.V. Дослідження сортових ресурсів трав’яних видів Раeonia L. в Україні. Науковий вісник НЛТУ України, 2018. 28(8), 74-78. Doi: 10.154 21/40280815.

2. Алексеева Н.Н., Яременко Л.М. Астры. Москва. Юнивест маркетинг, 1999. 30 c.

3. Алексєєва Н.М. Айстри. Квіти України. 2006. № 4. С. 6-8.

4. Былов В.Н. Основы сравнительной сортооценки декоративных растений. Интродукция и селекция цветочно-декоративных растений. Москва. Наука, 1978. С. 7-32.

5.Harris Moran Seeds: Professional Bedding Plant and Flower Growers Catalog. Rochester, 1987. 112 p.

6.Сампиев А.М., Хочава М.Р. Календула лекарственная. Краснодар: «Советская Кубань», 2010. 144 с.

7.Мазур В.А., Прокопчук В.М., Панцирева Г.В. Перспективність створення колекції півоній на базі ботанічного саду «Поділля» Вінницького національного аграрного університету. Збірник наукових праць. Сільське господарство та лісівництво. 2018. № 10. С. 5-18.

8. Державний реєстр сортів рослин, придатних для поширення в Україні на 2018 p. URL: http://vet.gov.ua/ sites/default/files/ReestrEU-2014-06-16.pdf.

9. Faizi S., Dar A., Siddiqi H., Naqvi S. Bioassay-guided isolation of antioxidant agents with analgesic properties from flowers of Tagetes patula [Text] Pharmaceutical Biology. 2011. Vol. 49. № 5. P. 516-525. Doi: 10.3109/13880209.2010.523006

10. Gong Y., Liu X., He W., Xu H. Investigation into the antioxidant activity and chemical composition of alcoholic extracts from defatted marigold (Tagetes erecta L.) residue [Text]. Fitoterapia. 2012. Vol. 83. № 3. P. 481-489. Doi:10.1016/ j.fitote.2011.12.013

11. Yasukawa K., Kasahara Y. Effects of Flavonoids from French Marigold (Florets of Tagetes patula L.) on Acute Inflammation Model. International Journal of Inflammation. 2013. Vol. 2013. P. 1-5. Doi:10.1155/2013/309493. 
12.Лаптєв О.О. Інтродукція та акліматизація рослин 3 основами озеленення. Київ: Фітосоціоцентр, 2001.109 с.

13.Cowling W.A. Plant breeding for stable agriculture: Presidential Address. Western Australia, 1994. P. 183-184.

14.Сахацька I.M. Встановлення жирнокислотного складу кореневищ 3 коренями півонії лікарської сортів «ALBA PLENA» та «ROSEA PLENA». Український медичний альманах, 2012. Том 15, № 1. С.139-140.

15.Прокопчук В. М. Первинна інтродукційна оцінка сортів Antirrhinum Majus в умовах біостаціонару Вінницького національного аграрного університету. Збірник наукових праць ВНАУ. Сільське господарство та лісівництво. 2017. Вип. 7 (Том 1). С. 113-120.

\section{Список використаної літератури у транслітерації / References}

1. Pantsyreva H.V. (2018). Research of sortal resources of grape species of Paeonia L. in Ukraine. Scientific Bulletin of UNFU, 28(8), 74-78. Doi:10.15421/40280815 [In Ukraine].

2. Alekseeva N.N., Yaremenko L.M. (1999). Astrы. [Istri]. Moskva. Yunyvest marketynh. [In Russian].

3. Aleksieieva N.M. (2006). Aistry [Istri]. Kvity Ukrainy. 4. 6-8. [In Ukraine].

4.Bulov V.N. (1987). Osnovы sravnytelnoi sortootsenky dekoratyvnыkh rastenyi. Yntroduktsyia y selektsyia tsvetochno-dekoratyvnukh rastenyi [Basics of comparative variety estimation of ornamental plants. Introduction and selection of flower and ornamental plants]. Moskva. Nauka. 7-32. [In Russian].

5. Harris Moran Seeds: Professional Bedding Plant and Flower Growers Catalog (1987). Rochester. [in United States].

6. Sampyev A.M., Khochava M.R. (2010). Kalendula lekarstvennaia [Calendula drug]. Krasnodar: «Sovetskaia Kuban». [In Russian].

7. Mazur V.A., Prokopchuk V.M., Pantsyreva H.V. (2018). Perspektyvnist stvorennia kolektsii pivonii na bazi botanichnoho sadu «Podillia» Vinnytskoho natsionalnoho ahrarnoho universytetu [Perspectives of creating a collection of peonies based on the Podillya botanical garden of the Vinnytsia National Agrarian University]. Zbirnyk naukovyx pracz`. Silske gospodarstvo ta lisivnycztvo Collection of scientific works. agriculture and forestry 10. 5-18. [In Ukraine].

8. Derzhavnyi reiestr sortiv roslyn, prydatnykh dlia poshyrennia v Ukraini na 2018 r. URL: http://vet.gov.ua/ sites/default/files/ReestrEU-2014-06-16.pdf). [In Ukraine].

9. Faizi S., Dar A., Siddiqi H., Naqvi S. (2011). Bioassay-guided isolation of antioxidant agents with analgesic properties from flowers of Tagetes patula. Pharmaceutical Biology. Vol. 49. № 5. R. 516-525. Doi: 10. 3109/13880209.2010.523006 [in United States].

10. Gong Y., Liu X., He W., Xu H. (2012). Investigation into the antioxidant activity and chemical composition of alcoholic extracts from defatted marigold 
(Tagetes erecta L.) residue. Fitoterapia. Vol. 8 3. № 3. R. 481-489. Doi:/10.1016/j. fitote.2011.12.013 [in United States].

11. Yasukawa K., Kasahara Y. (2013). Effects of Flavonoids from French Marigold (Florets of Tagetes patula L.) on Acute Inflammation Model International Journal of Inflammation. Vol. R. 1-5. Doi:10.1155/2013/309493 [In Ukraine].

12. Laptiev O.O. (2001). Introduktsiia ta aklimatyzatsiia roslyn z osnovamy ozelenennia [Introduction and acclimatization of plants with the basics of planting]. Kyiv: Fitosotsiotsentr. [In Ukraine].

13. Sowling W.A. (1994). Plant breeding for stable agriculture: Presidential Address. Western Australia. P. 183-184. [In Australia].

14.Sakhatska I.M. (2012). Vstanovlennia zhyrnokyslotnoho skladu korenevyshch z koreniamy pivonii likarskoi sortiv «ALBA PLENA» ta «ROSEA PLENA» [Establishment of fatty acid composition of rhizomes with roots of peony of medicinal varieties "ALBA PLENA" and "ROSEA PLENA"]. Ukrainskyi medychnyi almanakh. Vol. 15, 1. 39-140. [In Ukraine].

15.Prokopchuk V.M. (2017). Pervynna introduktsiina otsinka sortiv Antirrhinum Majus v umovakh biostatsionaru Vinnytskoho natsionalnoho ahrarnoho universytetu [Primary introductory evaluation of varieties of Antirrhinum Majus in the conditions of the Biostationary of Vinnytsia National Agrarian University. Zbirnyk naukovyx pracz`. Silske gospodarstvo ta lisivnycztvo - Collection of scientific works. agriculture and forestry. Issue 7 (Vols. 1). 113-120. [In Ukraine].

\section{АННОТАЦИЯ \\ СОВРЕМЕННОЕ СОСТОЯНИЕ И ПЕРСПЕКТИВЫ ИСПОЛЬЗОВАНИЯ ОДНОЛЕТНИХ ЦВЕТОЧНО-ДЕКОРАТИВНЫХ РАСТЕНИЙ В ОЗЕЛЕНЕНИИ ВИННИЦКОГО НАЦИОНАЛЬНОГО АГРАРНОГО УНИВЕРСИТЕТА}

Проанализировано современное состояние направлений использования однолетних изветочно-декоративных культур в зоне Подолья и определена их перспективность для озеленения парковой зоны ВНАУ. Изучено и исследовано наиболее перспективные виды и сорта культур семейства Астровые (Acteracea L.): ноготки лекарственные (Calendula officinalis L.), ичинния узколистный (Zinnia aqnustifolla H.), бархатизы прямостоячие (Tagetes erecta L.) и астра однолетняя (Callistephus chinensis L.) - экологически пластичных растений, устойчивых к лимитируюших факторам окружающей средьл $и$ с длительными декоративными свойствами в течение вегетационного периода. Выявлены наиболее перспективные сорта отечественной селекции для создания коллекиии однолетних культур на базе экспозиционного участка Винницкого национального аграрного университета: ноготки лекарственные (Солнцуе Египта, Каблуна, Гейша), цчинния узколистная (Глориенша, Сомбреро, Классик), бархатцуы прямостоячие (Титан, Вавила, Робин Гуд), 
астра однолетняя (Художественная, Яблоневая, Аметист). Изучая динамику продолжсительности иветения исследуемых сортов, установлено, что высокие показатели продолжительности иветения (до 60 дней) были установлены в Tagetes erecta L. (copm Титан - 52 дня, сорт Ванила - 60 дней, сорт Робин Гуд - 55 дней). Также нами обобщены рекомендации по использованию различных культиваров исследуемых однолетников зарубежной селекиии в озеленении с учетом их биоморфологичних особенностей. Установлено, что с практической точки зрения они являются перспективными для создания групп на фоне газона, миксбордеров, рабаток, клумб и является прекрасным материалом для создания моносада. Именно расширение вариантов простых и комплексных садовых композиций с их участием предоставит парковой зоне ВНАУ более декоративный вид, результаты исследований будут использованы для курса лекиий и практических занятий по программе специальности «Садовопарковое хозяйство» для студентов факультета агрономии и лесоводства Винницкого национального аграрного университета.

Ключевые слова: Acteracea L., культивар, природный ареал, период иветения, варианты использования, озеленение, ландшафтный дизайн.

Табл. 3. Рис. 1. Лит.15.

\section{ANNOTATION}

THE MODERN STATE AND THE PERSPECTIVES OF THE USE OF SINGLE-DIMENSIONAL FLOWER-DECORATIVE PLANTS IN THE GREENING OF THE PARK ZONE OF VINNYTSIA NATIONAL AGRARIAN UNIVERSITY

The present state of the trends of the use of annual flower-ornamental crops in the Podillya region is analyzed and their promise for landscaping of the park zone of $V N A U$ is determined. The most promising species and varieties of the cultures of the Astra family (Asteraceae L.) were studied and investigated: Medicinal leeches (Calendula officinalis L.), Zinnia aqnustifollia H., Rootsters (Tagetes erecta L.) and Astra annalistic (Callistephus chinensis L.), - ecologically plastic plants, resistant to limiting environmental factors and with long decorative properties during the growing season. The most promising varieties of domestic selection for the creation of a collection of annual crops on the basis of the exhibition area of the Vinnytsia National Agrarian University are found: medicinal herbs (Sun of Egypt, Kabloon, Geisha), cynic of the narrow-leaved (Gloriencha, Sombrero, Classic), black-eyed peoples (Titan, Vavila, Robin Good), astera annually (Artistic, Yablunevo, Amethyst). By studying the dynamics of the flowering time of the studied varieties, it was found that the highest flowering duration (up to 60 days) was found in Tagetes erecta L. (52 days for the Titan variety, 60 days for the Vanilla variety, 55 days for Robin Good variety). Also, we have generalized recommendations on the use of different cultivars of the studied annuals of foreign selection in landscaping, taking into account their biomorphological features. It is established that from a practical point of view, they are promising for creating groups on the background of the lawn, micoborts, 
rabatok, flower beds and is an excellent material for the creation of monosads. It is the expansion of variants of simple and complex garden compositions with their participation will give the park area VNAU more decorative, the results of research will be used for the course of lectures and practical classes on the program of the specialty «Landscape management» for students of the Faculty of Agronomy and Forestry Vinnytsa National Agrarian University.

Keywords: Acteracea L., cultivar, natural area, flowering period, use options, landscaping, landscape design.

Tabl. 3. Fig. 1. Lit.15.

\section{Інформація про автора}

Панцирева Ганна Віталіївна - кандидат сільськогосподарських наук, старший викладач кафедри лісового, садово-паркового господарства, садівництва та виноградарства Вінницького національного аграрного університету (21008, м. Вінниця, вул. Сонячна 3).

Панцырева Анна Витальевна - кандидат сельскохозяйственных наук, старший преподаватель кафедры лесового, садово-паркового хозяйства, садоводства и виноградарства Винницкого национального аграрного университета (21008, г. Винница, ул. Солнечная 3, e-mail: apantsyreva@ukr.net).

Pantsyreva Hanna Vitaliivna - Candidate of Agricultural Sciences, Senior Lecturer of the Department of Forestry, Horticulture, Horticulture and Viticulture, Vinnytsia National Agrarian University (21008, Vinnytsia, Soniachna Str.3). 